\title{
The Role of Mast Cells in Molding the Tumor Microenvironment
}

\author{
A. Rigoni • M. P. Colombo • C. Pucillo
}

Received: 31 January 2014 / Accepted: 20 August 2014 /Published online: 7 September 2014

(C) Springer Science+Business Media Dordrecht 2014

\begin{abstract}
Mast cells (MCs) are granulocytic immune cells that reside in tissues exposed to the external environment. MCs are best known for their activity in allergic reactions, but they have been involved in different physiological and pathological conditions. In particular, MC infiltration has been shown in several types of human tumors and in animal cancer models. Nevertheless, the role of MCs in the tumor microenvironment is still debated because they have been associated either to good or poor prognosis depending on tumor type and tissue localization. This dichotomous role relies on MC capacity to secrete a broad spectrum of molecules with modulatory functions, which may condition the final tumor outcome also promoting angiogenesis and tissue remodeling. In this review, we analyze the multifaceted role of mast cell in tumor progression and inhibition considering their ability to interact with: i) immune cells, ii) tumor cells and iii) the extracellular matrix. Eventually, the current MC targeting strategies to treat cancer patients are discussed. Deciphering the actual role of MCs in tumor onset and progression is crucial to identify MCtargeted treatments aimed at killing cancer cells or at making the tumor vulnerable to selected anti-cancer drugs.
\end{abstract}

Keywords Mast cell $\cdot$ Cancer $\cdot$ Immune responses · Immunosuppression $\cdot$ Extracellular matrix

\footnotetext{
A. Rigoni $\cdot$ M. P. Colombo $(\square)$

Molecular Immunology Unit, Department of Experimental Oncology and Molecular Medicine, Fondazione IRCCS Istituto Nazionale

Tumori, via Amadeo 42, 20133 Milan, Italy

e-mail: mario.colombo@istitutotumori.mi.it

C. Pucillo

Department of Medical and Biological Sciences, University of

Udine, 33100 Udine, Italy
}

\section{Introduction}

Mast cells (MCs) are versatile, tissue-homing secretory cells, which were first described by Paul Ehrlich in his doctoral thesis as cells reacting metachromatically with basic aniline dyes. He named these aniline-positive cells located in connective tissues "Mastzellen" (from the word 'mast' that means well-fed in German) in the belief that their granules contained large amounts of nutrients. He also reported MC increase in chronic inflamed tissues assuming they were providing nutritional support to damaged cells [1]. Few years later, MCs were shown to be localized at the periphery of tumors [2] and MC accumulation at the tumor edge gained prognostic significance in malignant melanoma, breast cancer and colorectal adenocarcinoma [3-5].

The discovery of the major role of histamine, heparin and proteases released from MC granules during allergic responses, indicated MCs as crucial players in anaphylactic reactions. Nevertheless, MCs were found able to release a broad spectrum of molecules involved in cell-cell contact and cell-extracellular matrix adhesion as well as to deliver co-stimulatory signals, opening the field of MC research to a variety of physiological and pathological conditions [6]. MCs are plastic and their capacity to selectively secrete a wide range of biologically active products depends on the type, property, strength and combination of the stimuli they receive. Accordingly, the effect of MC activation may be finely modulated by environmental cues, leading to promotion or suppression of innate and adaptive immune responses [7]. Both positive and negative activities exerted by MCs have been described in pathologic conditions such as bacterial and parasitic infections, autoimmune diseases, allograft rejection and tolerance but also in numerous chronic inflammatory disorders and cancer $[8,9]$. To all appearances quantitatively irrelevant, MCs do impinge upon immunity and tolerance through complex interactions with surrounding cells and tissues. 
In this review, we discuss the main aspects of MC biology that impact on tumor promotion or inhibition through the interaction with other cells of the immune system or with tumor cells and discuss the current MC targeting approaches as therapeutic opportunity in cancer.

\section{Mast Cell Origin, Distribution and Granule Composition}

MCs originate in the bone marrow (BM) from pluripotent hematopoietic stem cells and circulate in the blood as committed precursors. MCs acquire a mature phenotype in their homing tissues under the effect of local cytokines such as stem cell factor (SCF), nerve growth factor (NGF) and interleukins (IL)-3, -4 and -9 [10]. Nevertheless, the crucial factor for MC development, maturation and homeostasis is SCF, the ligand of the receptor tyrosine kinase c-kit, expressed on the surface of stromal cells or released in the microenvironment in its soluble form [11]. Accordingly, MCs express c-kit during all the phases of their differentiation and after complete maturation, when all the other BM-derived cells down regulate c-kit expression. SCF is a chemotactic agent for MCs and it is responsible for their migration or recruitment into tissues in both physiologic and pathologic conditions, such as inflammation and cancer [12]. MC accumulation can be found in SCF-secreting mouse and human tumors. In transformed breast tissue, for example, SCF-recruited MCs establish a complex crosstalk with immune and tumor cells that, altogether, generate an immunosuppressed microenvironment [13, 14]. In both mouse and man prostate cancer, according to SCF availability, MCs progressively accumulate from the early phase of prostate transformation until the appearance of advanced prostatic adenocarcinoma [15]. In the transgenic adenocarcinoma of mouse prostate (TRAMP) model [16], epithelial but not neuroendocrine (NE) tumors produce SCF, thus being highly infiltrated by MCs. On the other hand, NE foci of TRAMP mice tumors express c-kit, suggesting their possible competition with MCs for the available SCF, an event that may foster the idea of preventing the occurrence of aggressive NE tumors targeting c-kit [17].

In mice, two major subtypes of MCs have been described so far: mucosal MCs (MMCs) and connective tissue MCs (CTMCs). This classification was done on the basis of $\mathrm{MC}$ morphology, localization and content of proteases. Mouse mast cell protease (mMCP)- 1 and -2 are found in MMCs granules whereas mMCP-4, $-5,-6$, and carboxypeptidase A characterize CTMCs [10]. In humans, the functional homologs of mMCP4 and 6 , respectively called chymase and tryptase, are the main components of MC granules and the variable expression of these molecules allows the distinction between tryptase-only $\left(\mathrm{MC}_{\mathrm{T}}\right)$, both tryptase- and chymasepositive $\left(\mathrm{MC}_{\mathrm{TC}}\right)$ and a third minor population of chymaseonly $\left(\mathrm{MC}_{\mathrm{C}}\right) \mathrm{MCs}$ [18]. Each $\mathrm{MC}$ subtype preferentially populate a different area: $\mathrm{MC}_{\mathrm{T}}$ cells are abundant within the mucosa of the respiratory and gastrointestinal tracts, and increase in case of mucosal inflammation, whereas $\mathrm{MC}_{\mathrm{TC}}$ cells are located within connective tissues such as the dermis, submucosa of the gastrointestinal tract, heart and perivascular tissues [19]. Nevertheless, MCs are endowed with plastic potential and may shift from one subtype to another under the influence of specific microenvironmental stimuli (pro- or anti-inflammatory responses) in both humans and mice. The heterogeneity and plasticity of MCs undoubtedly contribute to their multifaceted capacity to inhibit or promote malignant diseases $[20,7]$.

\section{Receptors and Mediators}

MC homing tissues are mucosal surfaces located at the interface between external and internal environment. Therefore, MCs are the first immune cells that interact with exogenous antigens and allergens becoming central in the maintenance of immune and tissue homeostasis in the genitourinary system [21], respiratory tract [22] and gut mucosa [23].

The best-known mechanism of MC activation is the engagement of the high-affinity receptor for IgE immunoglobulins (Fc\&RI) that activates anaphylactic reactions [24]. Nevertheless, for sensing the exogenous environment, MCs are also equipped with other membrane bound and intracellular receptors (summarized in Fig. 1). The function of these receptors

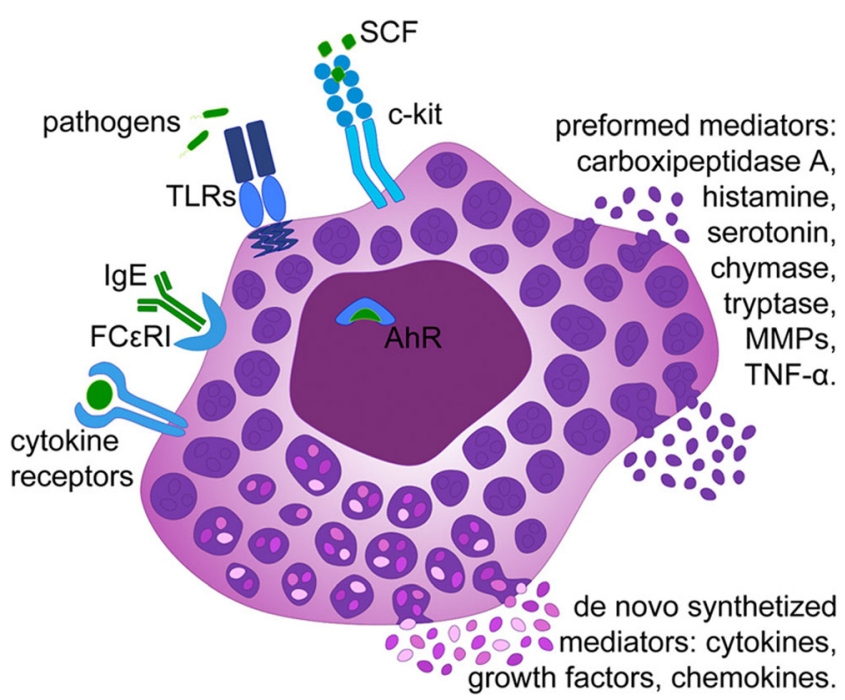

Fig. 1 Mast cell receptors and mediators. Schematic illustration representing signals mediating mast cell activation and release of mediators. Mast cells express membrane (c-kit, FceRI, TLRs, cytokine receptors) and intracellular receptors (AhR) which activity may be further modulated by costimulatory and coinhibitory molecules. After activation, MCs may immediately release soluble mediators prestored in their granules (carboxipeptidase A, histamine, serotonin, heparin, tryptase, chymase and tumor necrosis factor (TNF)- $\alpha$ ) or activate de novo synthesis of growth factors, chemokines and pro- (IL-1, IL-6, IL-17) or anti- (IL-10, tumor growth factor (TGF)- $\beta$ ) inflammatory cytokines 
may be finely tuned by costimulatory molecules (OX40L, CD40L, CD80, CD86, PD-L1, PD-L2) and by several receptors for cytokines such as IL-9, IL-18, IL-33 [7, 25]. The crosstalk between different receptors on MC surface might result in co-activation (synergism or additive effects) or inhibition of MC responses [26].

Among the molecules involved in sensing the external environment, the intracellular Aryl hydrocarbon receptor (AhR) has a central role. AhR detects and responds to several compounds derived from food digestion or from heme and tryptophan metabolism as well as to pollution toxins such as dioxin, dioxin-like compounds, and benzopyrene found in cigarette smoke [27]. Furthermore, AhR is involved in lung carcinogenesis in mice [28] and its expression positively correlates with non-small cell lung cancer in humans [29]. The constitutive activation of AhR in mouse models has been also shown to promote carcinogenesis in stomach [30] and in liver, a site where AhR is triggered by 2,3,7,8tetrachlorodibenzo- $p$-dioxin (TCDD), one of the most potent hepatotropic carcinogens in mice [31]. Nevertheless, the cancer promoting activity of AhR has been not completely clarified yet, neither in mouse nor in humans. Recently, AhR has been indicated to regulate the outcome of inflammatory bowel disease (IBD); in this setting, AhR activation in the gut leads to a diminished production of pro-inflammatory cytokines by $\mathrm{T}$ cells contributing to a better colitis outcome [32,33]. These observations suggest the possible use of natural or synthetic AhR-ligands to treat IBD. Moreover, BM-derived MCs constitutively express AhR and its triggering by AhR highaffinity ligand 6-formylindolo[3,2- $\beta]$ carbazole (FICZ) induces MC degranulation [34]. Therefore, AhR ligands and inhibitors might modulate MC activity helping to maintain or restore the homeostasis of tissues in which MCs are located.

After ligand-receptor interaction, MCs may release two main classes of soluble molecules: one is already preformed in granules and released immediately (histamine, serotonin, heparin, tryptase and chymase, TNF- $\alpha$ ), the other class requires de novo synthesis and it is released with a certain delay (lipid mediators, prostaglandins and pro- (IL-1, IL-6, IL-17) or anti(IL-10, TGF- $\beta$ ) inflammatory cytokines). The release of granules-stored molecules usually occurs through degranulation, a process in which the granules fuse with the plasma membrane to release their entire content. In other cases, a more tunable process called 'piecemeal degranulation' is activated to permit the release of specific mediators after vesicular transport towards the plasma membrane. The choice between one and the other mechanism of granule release depends on the integration of different signals coming from molecules such as antigens, cytokines, growth factor and hormones [35]. Also, tumor cells may foster their own growth and neovascularization hijacking this controlled release of mediators. On the contrary, the release of a broad spectrum of cytokines and factors during degranulation is usually detrimental for tumor development [20].

\section{Interaction with Other Tumor-Infiltrating Immune Cells}

The role of MCs in shaping immune responses has been recently unveiled. MCs may mobilize and modulate the activity of $\mathrm{T}$ cells, regulatory $\mathrm{T}$ (Treg) cells, antigen-presenting cells (APC) and myeloid-derived suppressor cells (MDSCs) with their soluble mediators or through cell-cell contact. Interacting with other immune cells, MC may regulate both innate and adaptive immunity, tuning the host responses toward developing cancers and influencing the clinical outcome of several tumors. During degranulation, MCs release a large variety of mediators that could intervene in the immune response in an unpredictable manner. Also, the context and the timing of MC activation play a fundamental role on the positive or negative effect of MCs on tumor growth and progression. The complex network of interactions between MCs and other components of the tumor microenvironment are summarized in Fig. 2.

Histamine, a biogenic amine classically released by MCs during allergic reactions, may modulate the chronic inflammatory response associated with developing neoplasms. Histamine exerts its biological effects binding four Gprotein-coupled receptors that differ in tissue expression patterns and functions, making complex the study of histamine activity in shaping inflammation of the tumor microenvironment. Furthermore, histamine may directly and indirectly influence $\mathrm{T}$ cell function. For instance, histamine released by MCs during inflammation regulates $\mathrm{T}$ cell polarization, enhancing T helper 1 (Th1) responses through the histamine receptor type 1 (H1R) while inhibiting both Th1 and $\mathrm{Th} 2$ responses through the $\mathrm{H} 2 \mathrm{R}$, as a consequence of the activation of different intracellular signaling pathways [36]. Alternatively, acting on peripheral monocytes through the $\mathrm{H} 2 \mathrm{R}$, histamine induces IL-10 production and reduces IL12 secretion, polarizing engaged naive $\mathrm{CD} 4^{+} \mathrm{T}$ cells toward a Th2 phenotype [37]. Thus, excessive secretion of histamine may result in a shift of Th1/Th2 balance toward Th2dominance that promotes the development of infections and tumors, normally inhibited by Th1-dependent immune mechanisms. It has also been shown that histamine could favor the creation of an immune suppressive microenvironment through the recruitment of Treg cells to the site of inflammation [38]. Moreover, the pleiotropic effects of histamine in immune modulation have made histamine receptor antagonists commonly used drugs not only in allergy but also in gastrointestinal inflammation and other immunerelated diseases such as cancer [39]. For example, H2R antagonists are known to inhibit the proliferation of several human colon carcinoma cell lines and the growth of transplanted colon carcinomas and melanomas [40].

MCs establish a bidirectional crosstalk with Treg cells through the OX40/OX40ligand (OX40L) axis. Treg cells 
Fig. 2 Mast cells in the tumor microenvironment. Mast cells are recruited at the tumor site by chemotactic factors released by cancer cells. Mast cell mediators influence cancer cell growth and survival but also the processes of angiogenesis, invasion and metastasis through extracellular matrix remodeling. MCs also establish a crosstalk with other tumor-infiltrating immune cells thus altering the final tumor outcome. Some of the interactions mentioned in this review are depicted in the figure

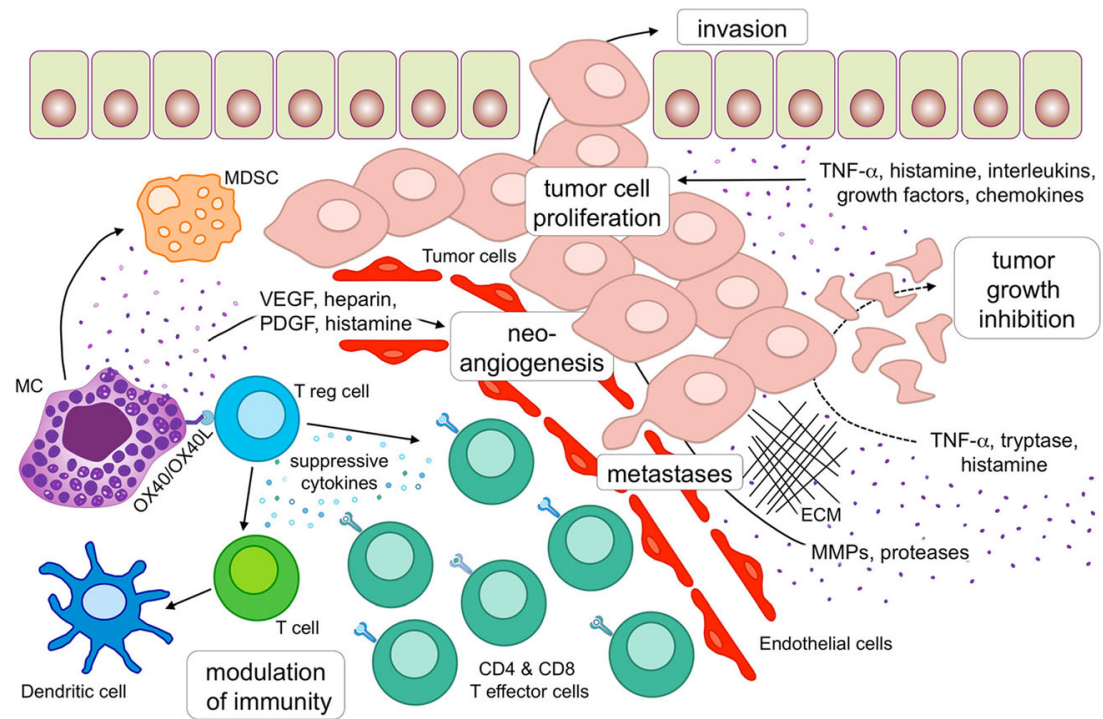

can engage OX40L on MC surface inhibiting histamine release in anaphylactic reactions [41]; on the other hand, under local availability of IL-6, MCs can revert Treg cells suppressive activity triggering OX40 on their membrane a setting that promotes Treg cells diversion from immunosuppressive into pro-inflammatory IL-17 producing cells [42]. Increased OX40/OX40L expression levels in the gut have been associated with inflammation that characterize IBD [43] and, accordingly, the interaction between OX40L on MCs and OX40 on Treg cells may play major roles in colitis and cancer. Activation of the OX40/OX40L pathway has been shown to be crucial for the development of T cell-induced colon inflammation because OX40L expression on activated DCs of the mesenteric lymph node (MLN) drives colitis pathogenesis. In this setting, $\mathrm{OX} 40 \mathrm{~L}^{+} \mathrm{DCs}$ drive the uncontrolled Th1 effector cells expansion that in turn increases the level of inflammation and triggers a further recruitment of DCs to the inflamed colon. Importantly, concomitant transfer of Treg cells prevents the expansion of $\mathrm{OX}_{40 \mathrm{~L}^{+}} \mathrm{DC}$ in the MLN, indicating that inhibition of DC activation is a mechanisms exploited by Treg cells to avoid excessive immune responses [44]. In this scenario, it is possible to speculate that $\mathrm{OX} 40 / \mathrm{OX} 40 \mathrm{~L}$ axis may become a therapeutic target for pathologies characterized by immune deregulation, such as IBDs.

A critical step in the establishment of an immunosuppressive microenvironment favorable for tumor growth is dependent on the T-Treg cells ratio. MCs, T and Treg cells create a complex network of interactions, controlling each other reciprocally. MCs can enhance $\mathrm{T}$ cell migration to the tumor microenvironment by altering vasculature permeability or directly modulating their function, activation and polarization toward a specific phenotype. On the other side, Treg cells inhibit MC differentiation and degranulation in a cell-cell contact manner or through the production of soluble factors [41, 42, 45].
The importance of MC-Treg cells interaction in the tumor microenvironment has been long debated in colon polyposis and cancer $[46,47]$ but the contribution of this interaction in the pathogenesis of gastrointestinal diseases has not been clarified yet. Khazaie and colleagues contributed to dissect how MC-Treg cells crosstalk influences colon polyposis and colorectal cancer in mouse and humans. They showed how in premalignant adenomatous lesions of $\mathrm{APC}^{\triangle 468}$ mice, an autocrine loop due to TNF- $\alpha$ production favors MCs precursor proliferation and the subsequent increase in MC number [48]. In polyps, mastocytosis is accompanied and amplified by the expansion of IL-17-producing Treg cell population that creates a cancer promoting inflammatory response [49]. Recent evidences also suggest that local inflammation occurring in colonic polyposis not only depends on the local T cell phenotype but also on gut microbial communities. In $\mathrm{APC}^{\Delta 468}$ mice developing spontaneous polyposis, colonic $\mathrm{T}$ and Treg cells are the major cellular sources of IL-10, critical cytokine in the control of microbial-induced inflammation that lead polyp growth. Accordingly, selective ablation of IL-10 in T cells but also complete IL-10 deficiency increases polyp frequency and reduces $\mathrm{MC}$ numbers [50].

Furthermore, in the $\mathrm{APC}^{\Delta 468}$ murine model, MCs could support MDSC activity in driving immune escape with a subsequent increase in polyp development [51]. Also, in a mouse model of melanoma, MDSCs were dependent on MCs to exert their suppressive function [52]. In human, the interaction between $\mathrm{MCs}$ and $\mathrm{CD} 14^{+} \mathrm{CD} 19^{+} \mathrm{HLA}_{-} \mathrm{DR}^{-/ \mathrm{low}}$ MDSCs seem to create an immunosuppressive microenvironment at least in patients affected by colon cancer and melanoma [53]. Indeed, in transformed tissues MCs can respond to local SCF producing CCL-2 that in turn mobilize and recruit MDSCs within the tumor lesion [14]. Additionally, MDSCderived IL-17 has been indicated to recruit Treg cells, which may increase MC survival providing IL-9 [54]. 
These recent findings describing the interactions between MCs, Treg cells and MDSCs, suggest that a plethora of immune interplays may concur to create an immunosuppressive tumor microenvironment and that the inhibition of such interactions might offer therapeutic opportunities.

\section{Influence on Tumor Development, Progression and Outcome}

In human cancers, MCs may populate the tumor invasive or infiltrate the stroma. The large variability in type, grade or stage of human tumors, and the poorly characterized distribution of MCs in tumors, do not allow unambiguous classification of MC function as pro- or anti-tumorigenic (Table 1). The study of MCs in hematologic malignances provides an example of this paradigmatic situation. In Hodgkin's lymphoma, MC infiltration has been correlated with a shorter relapsefree survival [55]. In splenic marginal zone lymphoma, a Bcell neoplasm with an indolent clinical course, a sudden and rapid progression may occur in some patients without any possibility of prediction. In the transformed splenic microenvironment, $\mathrm{CD} 40 \mathrm{~L}$ on MCs interacts with $\mathrm{CD} 40^{+}$mesenchymal cells stimulating the production of trophic factors for malignant B cells. Thus, the dense network of interactions created between stromal, immune and tumor cells impacts on time to progression and may represent a new target for therapy [56]. On the contrary, a high MC count is associated with favorable disease outcome in diffuse large B-cell lymphoma [57]. Even though the pathogenesis driving T cell neoplasms is not completely understood due to their low prevalence, neoplastic clones of angioimmunoblastic T-cell lymphomas

Table 1 Correlation between MC infiltration and tumor outcome

\begin{tabular}{|c|c|c|c|}
\hline Tumor & Prognosis & Brief description of MC activity & Ref \\
\hline \multirow[t]{2}{*}{ Breast cancer } & Good & Stromal mast cell infiltration, even in small quantity, is a good prognostic marker in breast cancer & {$[85]$} \\
\hline & Good & $\begin{array}{l}\text { Mast cells are recruited by stem cell factor and produce a immunosuppressed tumor } \\
\text { microenvironment }\end{array}$ & {$[14]$} \\
\hline \multirow[t]{3}{*}{ Colorectal cancer } & Poor & High micro vessels density and mast cell number is associated with metastases and shorter survival & {$[67]$} \\
\hline & Poor & High density of mast cells at the invasive margin of tumors favors colorectal cancer progression & {$[68]$} \\
\hline & Poor & In polyps, mast cells and their precursors sustain inflammation and progression to cancer & {$[48]$} \\
\hline \multirow{2}{*}{$\begin{array}{l}\text { Esophagus squamous cell } \\
\text { carcinoma }\end{array}$} & Good & Mast cells sustain antitumor immunity producing IL-17 and predict a favorable prognosis & {$[86]$} \\
\hline & Poor & $\begin{array}{l}\text { High mast cells number at the invasive edge of tumor favors tumor progression and decreases } \\
\text { survival rate post-surgery }\end{array}$ & {$[87]$} \\
\hline Gastrointestinal cancer & Poor & Number of mast cells expressing tryptase is correlated with lymph node metastatization post surgery & {$[88]$} \\
\hline Hepatocellular carcinoma & Good & High density of mast cells predicts late recurrence & [89] \\
\hline \multirow[t]{2}{*}{ Lung cancer } & Good & $\begin{array}{l}\text { Mast cells infiltration of non-small cell lung cancer is associated with increase in 5-year survival, } \\
\text { independently of tumor stage }\end{array}$ & {$[90]$} \\
\hline & Poor & In lung adenocarcinoma, mast cell density correlates with angiogenesis and poor prognosis & {$[91,92]$} \\
\hline \multirow[t]{2}{*}{ Malignant melanoma } & Poor & $\begin{array}{l}\text { Higher mast cell number found in invasive melanoma compared with benign nevi or in situ } \\
\text { melanoma }\end{array}$ & [93] \\
\hline & Poor & High mast cell number correlates with high microvessels density and poor prognosis & [94] \\
\hline Neurofibromatosis & Poor & Mast cells sustain neurofibromas initiation and progression & {$[61]$} \\
\hline \multirow[t]{3}{*}{ Pancreatic cancer } & Poor & $\begin{array}{l}\text { Higher mast cell number in pancreatic cancer than in normal pancreas; mast cell number correlates } \\
\text { with metastatic potential }\end{array}$ & [95] \\
\hline & Poor & Tumor stroma infiltration by mast cells is associated with poor prognosis & [96] \\
\hline & Poor & High mast cells number at the tumor edge correlates with invasion, metastasis and tumor staging & [97] \\
\hline \multirow[t]{3}{*}{ Prostate cancer } & Good & Intratumoral mast cells negatively regulate angiogenesis and tumor growth & [98] \\
\hline & Poor & Peritumoral mast cells stimulate the expansion of tumor & [98] \\
\hline & Poor & Mast cells favors the progression to adenocarcinoma but are absent in neuroendocrine tumor foci & {$[15]$} \\
\hline $\begin{array}{l}\text { Primary cutaneous } \\
\text { lymphoma }\end{array}$ & Poor & High mast cell number at tumor periphery is associated with progressive disease & {$[59]$} \\
\hline $\begin{array}{l}\text { Diffuse large B-cell } \\
\text { lymphoma }\end{array}$ & Good & High mast cell count is associated with a favorable disease outcome & {$[57]$} \\
\hline Hodgkin's lymphoma & Poor & High number of infiltrating mast cell is associated with worse relapse-free survival & {$[55]$} \\
\hline $\begin{array}{l}\text { Splenic marginal zone } \\
\text { lymphoma }\end{array}$ & Poor & Mast cell interaction with stromal cells impact on disease progression & {$[56]$} \\
\hline $\begin{array}{l}\text { Angioimmunoblastic } \\
\text { T-cell lymphoma }\end{array}$ & Poor & $\begin{array}{l}\text { Mast cell accumulation helps neoangiogenesis and characterize angioimmunoblastic T-cell } \\
\text { lymphomas }\end{array}$ & {$[58]$} \\
\hline
\end{tabular}


(AITL) can recruit MCs via CXCL-13 enriching the microenvironment in cells producing VEGF and TNF- $\alpha$ to initiate the neoangiogenetic process. Such MC abundance acquires clinical relevance because it occurs in AITL-infiltrated tissues and not in other peripheral T-cell lymphomas [58]. In patients with primary cutaneous lymphoma, a high MC count was correlated with poor prognosis, suggesting the use of $\mathrm{MC}$ infiltration as a prognostic marker for this disease [59].

MC infiltration has a clinical significance also in neurofibromatosis type 1, a genetic disorder that causes tumors to form on nerve tissue. MCs sustain neurofibromas initiation, progression and angiogenesis releasing their mediators [60]. MC interaction with nerve cells is mediated by substance $\mathrm{P}$, a neuropeptide known to enhance mucosal MC activity also in chronic inflammation of IBD. This suggests that interaction between neuronal fibers and MCs may lead to amplification and perpetuation of inflammatory damage in IBD [61].

The link between persistent inflammation and tissue transformation is now solid and best represented by colorectal cancer development in patients affected by IBD [62]. Even though the body of literature is growing exponentially, no conclusive data exist about the actual role of MCs in inflammatory diseases other than allergic reactions. The presence of morphologically activated or degranulated MCs in colon during the florid phase of the inflammatory process suggests their possible role in the transition from inflammation to carcinoma. Nevertheless, MCs have been shown to sustain or resolve colon inflammation with results depending on the mouse model and on the experimental settings under investigation. MC deficiency due to c-kit mutations has been shown to be protective in two studies of chemically induced colorectal cancer and pro-tumorigenic in other works carried out in APC mutated polyp-prone mice [63].

Heterogeneous MC functions have been also described in other murine models of inflammation-related carcinogenesis. In IBD-susceptible IL-10-deficient (IL-10 ${ }^{-/-}$) mice, MCs appear to have a primarily protective role within the colonic mucosa [64] whereas in the piroxicam/IL- $10^{-1-}$ mouse model of progressive colitis, MCs and tumorassociated macrophages promoted cancer cells invasion. This tumor promoting activity has been explained considering $\mathrm{MC}$ ability to attract $\mathrm{CD} 11 \mathrm{~b}^{+}$cells, in an ex-vivo migration assay, through the activation of the phosphoinositide 3kinases (PI3Ks) signaling cascade. Both inflamed human gut and piroxicam/IL- $10^{-/-}$mouse colons infiltrated by MCs also show an active PI3K/AKT pathway, assessed by immunostaining of phosphorylated AKT, likely responsible for the further recruitment of inflammatory cells [65]. These findings indicate that colitis and progression to cancer are influenced by the interaction between stromal and immune cells and that the pharmacological inhibition of kinase activity could antagonize such vicious loop.
Also, the direct inhibition of inflammation using antiTNF- $\alpha$ blocking antibodies can reduce the incidence of cancer by diminishing the recruitment of inflammatory cells within the transformed colonic epithelium. For example, the antitumor activity of infliximab, a monoclonal antibody against $\mathrm{TNF}-\alpha$, is due to the inactivation of mucosal MCs in animal models of inflammation-induced colorectal cancer [66].

Accordingly, MC localization at the edge of human colorectal tumors is associated with bad prognosis likely for their ability to promote neoangiogenesis and invasion [67, 68]. MCs have been also shown to accumulate [69] and release their granule content [23] in course of human IBD, but no conclusive data exist about their precise role in the carcinogenesis process.

\section{MC and Extracellular Matrix During Tumor Development}

The extracellular matrix (ECM) is an organized network of molecules in which both normal and tumor cells reside. ECM may regulate migration, adhesion and function of both normal and tumor cells under the pressure of microenvironmental signals [70]. Cancer cells, but also endothelial cells, fibroblasts, inflammatory cells and pericytes recruited to the tumor, are able to secrete ECM proteins. In physiological conditions the stroma contributes to the maintenance of ECM structural integrity whereas, during transformation toward cancer, stromal cells can modify their function, thus the composition of ECM, influencing tumor clinical outcome [71].

MCs participate in physiological and pathological ECM modifications. During mammary gland development, MCs sustain normal proliferation of cells in ducts helping tissue remodeling and angiogenesis through their proteases [72]. Not surprisingly, MCs have also a role in tumor tissue rearrangement that favors invasion and metastatization. In human colon adenocarcinomas, tryptase-positive MCs colonize the invasive front of tumor and tryptase seems to help tumor cell motility and metastasis dissemination via the proteaseactivated receptor-2 (PAR-2) [68]. Tryptase-activated PAR-2 in human colon carcinoma cell lines induces cell proliferation through the production of $\mathrm{PGE}_{2}$ [73]. Interestingly, $\mathrm{PGE}_{2}$ has also been found to induce the production of vascular endothelial growth factor in human MCs [74], suggesting the creation of a loop that promotes tumorigenesis.

The early phases of cutaneous squamous carcinoma onset require inflammatory MCs to reorganize stromal architecture of hyperplastic tissues and promote angiogenesis at the invasive tumor front through matrix metalloproteinase (MMP)-9. This process lasts until cancer cells become capable to autonomously produce pro-angiogenetic factors [75]. The link between MCs and MMP-9 in cancer promotion is also well 
exemplified in mouse and human prostate cancer. MCs are able to favor the initial stage of adenocarcinoma development providing MMP-9 that supports ECM remodeling, angiogenesis and invasion while tumor cells are incapable to produce it. At later stages of tumor progression and following epithelialmesenchymal transition, MCs become dispensable because poor differentiated tumor cells start to produce MMP-9 by themselves. Accordingly, advanced tumors are almost devoid of infiltrating MCs both in mouse and in humans [15, 17].

\section{MCs as Therapeutic Targets}

MC inhibition with a therapeutic purpose has been widely exploited using histamine antagonists against allergic reactions. However, in the last decades, novel targets on MCs have been identified, offering new therapeutic opportunities for numerous inflammatory diseases and perhaps for cancer. Such new targets can be soluble mediators, membrane molecules and intracellular pathways (reviewed in [76]).

Tryptase, the major component of MC granules, may intervene in MC-mediated tissue regulation in several ways. The use of tryptase inhibitors is essentially related to allergic responses even though the discovery of their efficacy in inflammation and host defense suggested a possible use in the treatment of other pathologies, such as cancer [77]. Nevertheless, tryptase inhibitors have not entered the clinical practice yet, likely because of their low efficacy. MCs can also release different MMPs, molecules that have been strongly implicated in tumor progression. MMPs inhibitors have been tested in the clinic with unsatisfactory results in cancer due to adverse effects and low specificity $[78,79]$.

Another widely used approach in allergy is MC blocking through sodium cromoglycate (cromolyn), a drug that prevents the release of $\mathrm{MC}$ mediators during degranulation with a not completely understood mechanism. Even if a recent study has strongly questioned cromolyn activity in both in vitro and in vivo settings [80], this drug was effective in some experimental studies. In mouse models of mammary adenocarcinoma and pancreatic cancer, cromolyn treatment induced apoptosis of tumor cells due to clotting in blood vessels and hypoxia [81]. In prostate tumors of TRAMP mice, cromolyn chronic treatment inhibited the development of adenocarcinomas that rely on MC for MMP-9 provision [15]. Despite that, cromolyn is not commonly used in the clinical practice because it is a rather weak inhibitor of human $\mathrm{MC}$ degranulation.

These pieces of information suggest to look for other targets and the receptor tyrosine kinase c-kit emerged as the one to aim at because MCs rely on its activation for development, survival, migration and activation. The first tyrosine kinase receptor inhibitors (TKIs) approved for clinical use, imatinib mesylate (Gleveec, Novartis, Basel, Switzerland), is currently used in the treatment of gastrointestinal stromal tumors and chronic myelocytic leukemia; unfortunately, it was not beneficial in breast carcinomas, ovarian and some endocrine tumors $[82,83]$. Also, imatinib has a clinical benefit in tumors such as neurofibromas and mastocytosis, which highly depend on MCs and on aberrant tyrosine kinase receptors activity for their growth. Nevertheless, some c-kit mutations that drives MC uncontrolled proliferation in mastocytosis are imatinib resistant [84]. Therefore, an alternative way to inhibit MCs could be the use of TKIs acting on other receptors such as spleen tyrosine kinase (SYK), PI3Ks, Src homology 2 domain-containing inositol 5' phosphatase 1 (SHIP-1) [76]. Nevertheless, to obtain a specific inhibition of $\mathrm{MC}$ activity, drugs acting on these molecules exclusively in MCs should be found.

In conclusion, although MC targeting is a real need in certain types of neoplasia, no suitable molecules are available yet suggesting that pointing at MC immunoregulatory function is a possible way to temper their pro-tumoral activities.

\section{Conclusion}

Overall, MCs seem mostly active at the site of tumor-host interaction where they mold the microenvironment to accommodate initial malignant transformation and to favor invasion of nearby normal tissues. MC activation occurs in response to signals received through a large array of receptors and culminates in the release of soluble molecules able to influence neighboring stromal, immune and tumor cells. MC immunological activities depend on the crosstalk with other immune cells whose modulation may contribute to either local immunosuppression or inflammation. However, MCs can directly modulate tumor cell activity and mold the tumor microenvironment modifying the extracellular matrix. The elucidation of the actual role of MCs in tumor development and progression, will give the opportunity to develop new MC-targeted therapies as part of combinatory treatments for cancer patients.

Acknowledgments This work was supported by grants from Fondazione Cariplo (number 2010-0790) and Associazione Italiana per la Ricerca sul Cancro (AIRC: Investigator Grant number 14194 to Mario Paolo Colombo). The work of Carlo Pucillo is supported by a grant from Associazione Italiana Mastocitosi (ASIMAS). Alice Rigoni is supported by a triennial fellowship from Fondazione Italiana per la Ricerca sul Cancro (FIRC).

\section{References}

1. Erlich P (1878) Beiträge zur Theorie und Praxis der histologischen Färbung. Dissertation, Leipzig University.

2. Westphal E (1891) Uber mastzellen. Hirschwald Press, Berlin 
3. Lachter J, Stein M, Lichtig C, Eidelman S, Munichor M (1995) Mast cells in colorectal neoplasias and premalignant disorders. Dis Colon Rectum 38(3):290-293

4. Ch'ng S, Sullivan M, Yuan L, Davis P, Tan ST (2006) Mast cells dysregulate apoptotic and cell cycle genes in mucosal squamous cell carcinoma. Cancer Cell Int 6:28. doi:10.1186/1475-2867-6-28

5. Amini RM, Aaltonen K, Nevanlinna H, Carvalho R, Salonen L, Heikkila P, Blomqvist C (2007) Mast cells and eosinophils in invasive breast carcinoma. BMC Cancer 7:165. doi:10.1186/1471-24077-165

6. Blank U, Falcone FH, Nilsson G (2013) The history of mast cell and basophil research - some lessons learnt from the last century. Allergy 68(9):1093-1101. doi:10.1111/all.12197

7. Tsai M, Grimbaldeston M, Galli SJ (2011) Mast cells and immunoregulation/immunomodulation. Adv Exp Med Biol 716:186-211. doi:10.1007/978-1-4419-9533-9_11

8. Metz M, Grimbaldeston MA, Nakae S, Piliponsky AM, Tsai M, Galli SJ (2007) Mast cells in the promotion and limitation of chronic inflammation. Immunol Rev 217:304-328. doi:10.1111/j.1600065X.2007.00520.x

9. Kalesnikoff J, Galli SJ (2008) New developments in mast cell biology. Nat Immunol 9(11):1215-1223. doi:10.1038/ni.f.216

10. Gurish MF, Austen KF (2012) Developmental origin and functional specialization of mast cell subsets. Immunity 37(1):25-33. doi:10. 1016/j.immuni.2012.07.003

11. Anderson DM, Lyman SD, Baird A, Wignall JM, Eisenman J, Rauch C, March CJ, Boswell HS, Gimpel SD, Cosman D et al (1990) Molecular cloning of mast cell growth factor, a hematopoietin that is active in both membrane bound and soluble forms. Cell 63(1):235243

12. Meininger CJ, Yano H, Rottapel R, Bernstein A, Zsebo KM, Zetter BR (1992) The c-kit receptor ligand functions as a mast cell chemoattractant. Blood 79(4):958-963

13. Ulivi P, Zoli W, Medri L, Amadori D, Saragoni L, Barbanti F, Calistri D, Silvestrini R (2004) c-kit and SCF expression in normal and tumor breast tissue. Breast Cancer Res Treat 83(1):33-42. doi:10.1023/ B:BREA.0000010694.35023.9e

14. Huang B, Lei Z, Zhang GM, Li D, Song C, Li B, Liu Y, Yuan Y, Unkeless J, Xiong H, Feng ZH (2008) SCF-mediated mast cell infiltration and activation exacerbate the inflammation and immunosuppression in tumor microenvironment. Blood 112(4):1269-1279. doi:10.1182/blood-2008-03-147033

15. Pittoni P, Tripodo C, Piconese S, Mauri G, Parenza M, Rigoni A, Sangaletti S, Colombo MP (2011) Mast cell targeting hampers prostate adenocarcinoma development but promotes the occurrence of highly malignant neuroendocrine cancers. Cancer Res 71(18):59875997. doi:10.1158/0008-5472.CAN-11-1637

16. Greenberg NM, DeMayo F, Finegold MJ, Medina D, Tilley WD, Aspinall JO, Cunha GR, Donjacour AA, Matusik RJ, Rosen JM (1995) Prostate cancer in a transgenic mouse. Proc Natl Acad Sci U S A 92(8):3439-3443

17. Pittoni P, Colombo MP (2012) The dark side of mast cell-targeted therapy in prostate cancer. Cancer Res 72(4):831-835. doi:10.1158/ 0008-5472.CAN-11-3110

18. Irani AA, Schechter NM, Craig SS, DeBlois G, Schwartz LB (1986) Two types of human mast cells that have distinct neutral protease compositions. Proc Natl Acad Sci U S A 83(12):4464-4468

19. Stone KD, Prussin C, Metcalfe DD (2010) IgE, mast cells, basophils, and eosinophils. J Allergy Clin Immunol 125(2 Suppl 2):S73-S80. doi:10.1016/j.jaci.2009.11.017

20. Theoharides TC, Conti P (2004) Mast cells: the Jekyll and Hyde of tumor growth. Trends Immunol 25(5):235-241. doi:10.1016/j.it. 2004.02.013

21. Mori A, Zhai YL, Toki T, Nikaido T, Fujii S (1997) Distribution and heterogeneity of mast cells in the human uterus. Hum Reprod 12(2): 368-372
22. Gelfand EW (2004) Inflammatory mediators in allergic rhinitis. J Allergy Clin Immunol 114(5 Suppl):S135-S138. doi:10.1016/j.jaci. 2004.08.043

23. Bischoff SC (2009) Physiological and pathophysiological functions of intestinal mast cells. Semin Immunopathol 31(2):185-205. doi:10. 1007/s00281-009-0165-4

24. Rivera J, Gilfillan AM (2006) Molecular regulation of mast cell activation. J Allergy Clin Immunol 117(6):1214-1225. doi:10. 1016/j.jaci.2006.04.015, quiz 1226

25. Migalovich-Sheikhet H, Friedman S, Mankuta D, Levi-Schaffer F (2012) Novel identified receptors on mast cells. Front Immunol 3: 238. doi:10.3389/fimmu.2012.00238

26. Karra L, Levi-Schaffer F (2011) Down-regulation of mast cell responses through ITIM containing inhibitory receptors. Adv Exp Med Biol 716:143-159. doi:10.1007/978-1-4419-9533-9 9

27. Gu YZ, Hogenesch JB, Bradfield CA (2000) The PASS superfamily: sensors of environmental and developmental signals. Annu Rev Pharmacol Toxicol 40:519-561. doi:10.1146/annurev.pharmtox.40. 1.519

28. Matsumoto Y, Ide F, Kishi R, Akutagawa T, Sakai S, Nakamura M, Ishikawa T, Fujii-Kuriyama Y, Nakatsuru Y (2007) Aryl hydrocarbon receptor plays a significant role in mediating airborne particulateinduced carcinogenesis in mice. Environ Sci Technol 41(10):37753780

29. Lin P, Chang H, Ho WL, Wu MH, Su JM (2003) Association of aryl hydrocarbon receptor and cytochrome P4501B1 expressions in human non-small cell lung cancers. Lung Cancer 42(3):255-261

30. Andersson P, McGuire J, Rubio C, Gradin K, Whitelaw ML, Pettersson S, Hanberg A, Poellinger L (2002) A constitutively active dioxin/aryl hydrocarbon receptor induces stomach tumors. Proc Natl Acad Sci U S A 99(15):9990-9995. doi:10.1073/pnas. 152706299

31. Moennikes O, Loeppen S, Buchmann A, Andersson P, Ittrich C, Poellinger L, Schwarz M (2004) A constitutively active dioxin/aryl hydrocarbon receptor promotes hepatocarcinogenesis in mice. Cancer Res 64(14):4707-4710. doi:10.1158/0008-5472.CAN-030875

32. Monteleone I, Rizzo A, Sarra M, Sica G, Sileri P, Biancone L, MacDonald TT, Pallone F, Monteleone G (2011) Aryl hydrocarbon receptor-induced signals up-regulate IL-22 production and inhibit inflammation in the gastrointestinal tract. Gastroenterology 141(1): 237-248, 248 e231. doi:10.1053/j.gastro.2011.04.007

33. Monteleone I, Pallone F, Monteleone G (2013) Aryl hydrocarbon receptor and colitis. Semin Immunopathol 35(6):671-675. doi:10. 1007/s00281-013-0396-2

34. Sibilano R, Frossi B, Calvaruso M, Danelli L, Betto E, Dall'Agnese A, Tripodo C, Colombo MP, Pucillo CE, Gri G (2012) The aryl hydrocarbon receptor modulates acute and late mast cell responses. J Immunol 189(1):120-127. doi:10.4049/jimmunol.1200009

35. Theoharides TC, Kempuraj D, Tagen M, Conti P, Kalogeromitros D (2007) Differential release of mast cell mediators and the pathogenesis of inflammation. Immunol Rev 217:65-78. doi:10.1111/j.1600065X.2007.00519.x

36. Jutel M, Watanabe T, Klunker S, Akdis M, Thomet OA, Malolepszy J, Zak-Nejmark T, Koga R, Kobayashi T, Blaser K, Akdis CA (2001) Histamine regulates $\mathrm{T}$-cell and antibody responses by differential expression of $\mathrm{H} 1$ and $\mathrm{H} 2$ receptors. Nature 413(6854):420-425. doi:10.1038/35096564

37. Elenkov IJ, Webster E, Papanicolaou DA, Fleisher TA, Chrousos GP, Wilder RL (1998) Histamine potently suppresses human IL-12 and stimulates IL-10 production via H2 receptors. J Immunol 161(5): 2586-2593

38. Morgan RK, McAllister B, Cross L, Green DS, Kornfeld H, Center DM, Cruikshank WW (2007) Histamine 4 receptor activation induces recruitment of FoxP3 + T cells and inhibits allergic asthma in a murine model. J Immunol 178(12):8081-8089 
39. Seifert R, Strasser A, Schneider EH, Neumann D, Dove S, Buschauer A (2013) Molecular and cellular analysis of human histamine receptor subtypes. Trends Pharmacol Sci 34(1):33-58. doi:10.1016/j.tips. 2012.11.001

40. Medina VA, Rivera ES (2010) Histamine receptors and cancer pharmacology. Br J Pharmacol 161(4):755-767. doi:10.1111/j.14765381.2010.00961.x

41. Gri G, Piconese S, Frossi B, Manfroi V, Merluzzi S, Tripodo C, Viola A, Odom S, Rivera J, Colombo MP, Pucillo CE (2008) CD4+CD25+ regulatory $\mathrm{T}$ cells suppress mast cell degranulation and allergic responses through OX40-OX40L interaction. Immunity 29(5):771781. doi:10.1016/j.immuni.2008.08.018

42. Piconese S, Gri G, Tripodo C, Musio S, Gorzanelli A, Frossi B, Pedotti R, Pucillo CE, Colombo MP (2009) Mast cells counteract regulatory T-cell suppression through interleukin-6 and OX40/ OX40L axis toward Th17-cell differentiation. Blood 114(13):26392648. doi:10.1182/blood-2009-05-220004

43. Souza HS, Elia CC, Spencer J, MacDonald TT (1999) Expression of lymphocyte-endothelial receptor-ligand pairs, alpha4beta7/ MAdCAM-1 and OX40/OX40 ligand in the colon and jejunum of patients with inflammatory bowel disease. Gut 45(6):856-863

44. Malmstrom V, Shipton D, Singh B, Al-Shamkhani A, Puklavec MJ, Barclay AN, Powrie F (2001) CD134L expression on dendritic cells in the mesenteric lymph nodes drives colitis in T cell-restored SCID mice. J Immunol 166(11):6972-6981

45. de Vries VC, Wasiuk A, Bennett KA, Benson MJ, Elgueta R, Waldschmidt TJ, Noelle RJ (2009) Mast cell degranulation breaks peripheral tolerance. Am J Transplant 9(10):2270-2280. doi:10. 1111/j.1600-6143.2009.02755.x

46. Grimbaldeston MA, Chen CC, Piliponsky AM, Tsai M, Tam SY, Galli SJ (2005) Mast cell-deficient W-sash c-kit mutant Kit W-sh/Wsh mice as a model for investigating mast cell biology in vivo. Am J Pathol 167(3):835-848. doi:10.1016/S0002-9440(10)62055-X

47. Colombo MP, Piconese S (2009) Polyps wrap mast cells and Treg within tumorigenic tentacles. Cancer Res 69(14):5619-5622. doi:10. 1158/0008-5472.CAN-09-1351

48. Gounaris E, Erdman SE, Restaino C, Gurish MF, Friend DS, Gounari F, Lee DM, Zhang G, Glickman JN, Shin K, Rao VP, Poutahidis T, Weissleder R, McNagny KM, Khazaie K (2007) Mast cells are an essential hematopoietic component for polyp development. Proc Natl Acad Sci U S A 104(50):19977-19982. doi:10.1073/pnas. 0704620104

49. Gounaris E, Blatner NR, Dennis K, Magnusson F, Gurish MF, Strom TB, Beckhove P, Gounari F, Khazaie K (2009) T-regulatory cells shift from a protective anti-inflammatory to a cancer-promoting proinflammatory phenotype in polyposis. Cancer Res 69(13):5490-5497. doi:10.1158/0008-5472.CAN-09-0304

50. Dennis KL, Wang Y, Blatner NR, Wang S, Saadalla A, Trudeau E, Roers A, Weaver CT, Lee JJ, Gilbert JA, Chang EB, Khazaie K (2013) Adenomatous polyps are driven by microbe-instigated focal inflammation and are controlled by IL-10-producing $\mathrm{T}$ cells. Cancer Res 73(19):5905-5913. doi:10.1158/0008-5472. CAN-13-1511

51. Cheon EC, Khazaie K, Khan MW, Strouch MJ, Krantz SB, Phillips J, Blatner NR, Hix LM, Zhang M, Dennis KL, Salabat MR, Heiferman M, Grippo PJ, Munshi HG, Gounaris E, Bentrem DJ (2011) Mast cell 5-lipoxygenase activity promotes intestinal polyposis in APCDelta468 mice. Cancer Res 71(5):1627-1636. doi:10.1158/ 0008-5472.CAN-10-1923

52. Saleem SJ, Martin RK, Morales JK, Sturgill JL, Gibb DR, Graham L, Bear HD, Manjili MH, Ryan JJ, Conrad DH (2012) Cutting edge: mast cells critically augment myeloid-derived suppressor cell activity. J Immunol 189(2):511-515. doi:10.4049/jimmunol.1200647

53. Mandruzzato S, Solito S, Falisi E, Francescato S, Chiarion-Sileni V, Mocellin S, Zanon A, Rossi CR, Nitti D, Bronte V, Zanovello P (2009) IL4Ralpha+myeloid-derived suppressor cell expansion in cancer patients. J Immunol 182(10):6562-6568. doi:10.4049/ jimmunol.0803831

54. Yang Z, Zhang B, Li D, Lv M, Huang C, Shen GX, Huang B (2010) Mast cells mobilize myeloid-derived suppressor cells and Treg cells in tumor microenvironment via IL-17 pathway in murine hepatocarcinoma model. PLoS One 5(1):e8922. doi:10.1371/ journal.pone.0008922

55. Molin D, Edstrom A, Glimelius I, Glimelius B, Nilsson G, Sundstrom C, Enblad G (2002) Mast cell infiltration correlates with poor prognosis in Hodgkin's lymphoma. Br J Haematol 119(1):122-124

56. Franco G, Guarnotta C, Frossi B, Piccaluga PP, Boveri E, Gulino A, Fuligni F, Rigoni A, Porcasi R, Buffa S, Betto E, Florena AM, Franco V, Iannitto E, Arcaini L, Pileri SA, Pucillo C, Colombo MP, Sangaletti S, Tripodo C (2014) Bone marrow stroma CD40 expression correlates with inflammatory mast cell infiltration and disease progression in splenic marginal zone lymphoma. Blood. doi:10.1182/ blood-2013-04-497271

57. Hedstrom G, Berglund M, Molin D, Fischer M, Nilsson G, Thunberg U, Book M, Sundstrom C, Rosenquist R, Roos G, Erlanson M, Amini RM, Enblad G (2007) Mast cell infiltration is a favourable prognostic factor in diffuse large B-cell lymphoma. Br J Haematol 138(1):68-71. doi:10.1111/j.1365-2141.2007.06612.x

58. Tripodo C, Gri G, Piccaluga PP, Frossi B, Guarnotta C, Piconese S, Franco G, Vetri V, Pucillo CE, Florena AM, Colombo MP, Pileri SA (2010) Mast cells and Th17 cells contribute to the lymphomaassociated pro-inflammatory microenvironment of angioimmunoblastic T-cell lymphoma. Am J Pathol 177(2):792802. doi:10.2353/ajpath.2010.091286

59. Rabenhorst A, Schlaak M, Heukamp LC, Forster A, Theurich S, von Bergwelt-Baildon M, Buttner R, Kurschat P, Mauch C, Roers A, Hartmann K (2012) Mast cells play a protumorigenic role in primary cutaneous lymphoma. Blood 120(10):2042-2054. doi:10.1182/ blood-2012-03-415638

60. Yang FC, Ingram DA, Chen S, Zhu Y, Yuan J, Li X, Yang X, Knowles S, Horn W, Li Y, Zhang S, Yang Y, Vakili ST, Yu M, Burns D, Robertson K, Hutchins G, Parada LF, Clapp DW (2008) Nf1-dependent tumors require a microenvironment containing Nf1+/- and c-kit-dependent bone marrow. Cell 135(3):437-448. doi:10.1016/j.cell.2008.08.041

61. Baratelli F, Le M, Gershman GB, French SW (2014) Do mast cells play a pathogenetic role in neurofibromatosis type 1 and ulcerative colitis? Exp Mol Pathol 96(2):230-234. doi:10.1016/j.yexmp.2014. 02.006

62. Eaden J (2004) Review article: colorectal carcinoma and inflammatory bowel disease. Aliment Pharmacol Ther 20(Suppl 4):24-30. doi: 10.1111/j.1365-2036.2004.02046.x

63. Heijmans J, Buller NV, Muncan V, van den Brink GR (2012) Role of mast cells in colorectal cancer development, the jury is still out. Biochim Biophys Acta 1822(1):9-13. doi:10.1016/j.bbadis.2010.12.001

64. Chichlowski M, Westwood GS, Abraham SN, Hale LP (2010) Role of mast cells in inflammatory bowel disease and inflammationassociated colorectal neoplasia in IL-10-deficient mice. PLoS One 5(8):e12220. doi:10.1371/journal.pone.0012220

65. Khan MW, Keshavarzian A, Gounaris E, Melson JE, Cheon EC, Blatner NR, Chen ZE, Tsai FN, Lee G, Ryu H, Barrett TA, Bentrem DJ, Beckhove P, Khazaie K (2013) PI3K/AKT signaling is essential for communication between tissue-infiltrating mast cells, macrophages, and epithelial cells in colitis-induced cancer. Clin Cancer Res 19(9):2342-2354. doi:10.1158/1078-0432.CCR-12-2623

66. Kim YJ, Hong KS, Chung JW, Kim JH, Hahm KB (2010) Prevention of colitis-associated carcinogenesis with infliximab. Cancer Prev Res (Phila) 3(10):1314-1333. doi:10.1158/1940-6207.CAPR-09-0272

67. Gulubova M, Vlaykova T (2009) Prognostic significance of mast cell number and microvascular density for the survival of patients with primary colorectal cancer. J Gastroenterol Hepatol 24(7):1265-1275. doi:10.1111/j.1440-1746.2007.05009.x 
68. Malfettone A, Silvestris N, Saponaro C, Ranieri G, Russo A, Caruso S, Popescu O, Simone G, Paradiso A, Mangia A (2013) High density of tryptase-positive mast cells in human colorectal cancer: a poor prognostic factor related to protease-activated receptor 2 expression. J Cell Mol Med 17(8):1025-1037. doi:10.1111/jcmm.12073

69. Frossi B, Gri G, Tripodo C, Pucillo C (2010) Exploring a regulatory role for mast cells: 'MCregs'? Trends Immunol 31(3):97-102. doi: 10.1016/j.it.2009.12.007

70. Schmidt DR, Kao WJ (2007) The interrelated role of fibronectin and interleukin-1 in biomaterial-modulated macrophage function. Biomaterials 28(3):371-382. doi:10.1016/j.biomaterials.2006.08. 041

71. Junttila MR, de Sauvage FJ (2013) Influence of tumour microenvironment heterogeneity on therapeutic response. Nature 501(7467):346-354. doi:10.1038/nature 12626

72. Lilla JN, Werb Z (2010) Mast cells contribute to the stromal microenvironment in mammary gland branching morphogenesis. Dev Biol 337(1):124-133. doi:10.1016/j.ydbio.2009.10.021

73. Yoshii M, Jikuhara A, Mori S, Iwagaki H, Takahashi HK, Nishibori M, Tanaka N (2005) Mast cell tryptase stimulates DLD-1 carcinoma through prostaglandin- and MAP kinase-dependent manners. J Pharmacol Sci 98(4):450-458

74. Abdel-Majid RM, Marshall JS (2004) Prostaglandin E2 induces degranulation-independent production of vascular endothelial growth factor by human mast cells. J Immunol 172(2):1227-1236

75. Coussens LM, Raymond WW, Bergers G, Laig-Webster M, Behrendtsen O, Werb Z, Caughey GH, Hanahan D (1999) Inflammatory mast cells up-regulate angiogenesis during squamous epithelial carcinogenesis. Genes Dev 13(11):1382-1397

76. Harvima IT, Levi-Schaffer F, Draber P, Friedman S, Polakovicova I, Gibbs BF, Blank U, Nilsson G, Maurer M (2014) Molecular targets on mast cells and basophils for novel therapies. J Allergy Clin Immunol. doi:10.1016/j.jaci.2014.03.007

77. Caughey GH (2007) Mast cell tryptases and chymases in inflammation and host defense. Immunol Rev 217:141-154. doi:10.1111/j. 1600-065X.2007.00509.x

78. Coussens LM, Shapiro SD, Soloway PD, Werb Z (2001) Models for gain-of-function and loss-of-function of MMPs. Transgenic and gene targeted mice. Methods Mol Biol 151:149-179

79. Shi ZG, Li JP, Shi LL, Li X (2012) An updated patent therapeutic agents targeting MMPs. Recent Pat Anticancer Drug Discov 7(1):74 101

80. Oka T, Kalesnikoff J, Starkl P, Tsai M, Galli SJ (2012) Evidence questioning cromolyn's effectiveness and selectivity as a 'mast cell stabilizer' in mice. Lab Invest 92(10):1472-1482. doi:10.1038/ labinvest.2012.116

81. Soucek L, Lawlor ER, Soto D, Shchors K, Swigart LB, Evan GI (2007) Mast cells are required for angiogenesis and macroscopic expansion of Myc-induced pancreatic islet tumors. Nat Med 13(10): 1211-1218. doi:10.1038/nm1649

82. Pierotti MA, Tamborini E, Negri T, Pricl S, Pilotti S (2011) Targeted therapy in GIST: in silico modeling for prediction of resistance. Nat Rev Clin Oncol 8(3):161-170. doi:10.1038/nrclinonc.2011.3

83. Ribatti D, Crivellato E (2011) Mast cells and tumors: from biology to clinic. In: Springer (ed) Mast cells and tumors: from biology to clinic.

84. Pittoni P, Piconese S, Tripodo C, Colombo MP (2011) Tumorintrinsic and -extrinsic roles of c-Kit: mast cells as the primary offtarget of tyrosine kinase inhibitors. Oncogene 30(7):757-769. doi:10. 1038/onc. 2010.494
85. Rajput AB, Turbin DA, Cheang MC, Voduc DK, Leung S, Gelmon KA, Gilks CB, Huntsman DG (2008) Stromal mast cells in invasive breast cancer are a marker of favourable prognosis: a study of 4,444 cases. Breast Cancer Res Treat 107(2):249-257. doi:10.1007/ s10549-007-9546-3

86. Wang B, Li L, Liao Y, Li J, Yu X, Zhang Y, Xu J, Rao H, Chen S, Zhang L, Zheng L (2013) Mast cells expressing interleukin 17 in the muscularis propria predict a favorable prognosis in esophageal squamous cell carcinoma. Cancer Immunol Immunother: CII 62(10): 1575-1585. doi:10.1007/s00262-013-1460-4

87. Fakhrjou A, Niroumand-Oscoei SM, Somi MH, Ghojazadeh M, Naghashi S, Samankan S (2013) Prognostic Value of TumorInfiltrating Mast Cells in Outcome of Patients with Esophagus Squamous Cell Carcinoma. J Gastrointest Cancer. doi:10.1007/ s12029-013-9550-2

88. Ammendola M, Sacco R, Donato G, Zuccala V, Russo E, Luposella M, Vescio G, Rizzuto A, Patruno R, De Sarro G, Montemurro S, Sammarco G, Ranieri G (2013) Mast cell positivity to tryptase correlates with metastatic lymph nodes in gastrointestinal cancer patients treated surgically. Oncology 85(2):111-116. doi:10.1159/ 000351145

89. Chen L, Zhang Q, Chang W, Du Y, Zhang H, Cao G (2012) Viral and host inflammation-related factors that can predict the prognosis of hepatocellular carcinoma. Eur J Cancer 48(13):1977-1987. doi:10. 1016/j.ejca.2012.01.015

90. Welsh TJ, Green RH, Richardson D, Waller DA, O'Byrne KJ, Bradding P (2005) Macrophage and mast-cell invasion of tumor cell islets confers a marked survival advantage in non-small-cell lung cancer. J Clin Oncol 23(35):8959-8967. doi:10.1200/JCO.2005.01. 4910

91. Imada A, Shijubo N, Kojima H, Abe S (2000) Mast cells correlate with angiogenesis and poor outcome in stage I lung adenocarcinoma. Eur Respir J 15(6):1087-1093

92. Takanami I, Takeuchi K, Naruke M (2000) Mast cell density is associated with angiogenesis and poor prognosis in pulmonary adenocarcinoma. Cancer 88(12):2686-2692

93. Duncan LM, Richards LA, Mihm MC Jr (1998) Increased mast cell density in invasive melanoma. J Cutan Pathol 25(1):11-15

94. Ribatti D, Ennas MG, Vacca A, Ferreli F, Nico B, Orru S, Sirigu P (2003) Tumor vascularity and tryptase-positive mast cells correlate with a poor prognosis in melanoma. Eur J Clin Investig 33(5):420-425

95. Esposito I, Menicagli M, Funel N, Bergmann F, Boggi U, Mosca F, Bevilacqua G, Campani D (2004) Inflammatory cells contribute to the generation of an angiogenic phenotype in pancreatic ductal adenocarcinoma. J Clin Pathol 57(6):630-636

96. Strouch MJ, Cheon EC, Salabat MR, Krantz SB, Gounaris E, Melstrom LG, Dangi-Garimella S, Wang E, Munshi HG, Khazaie K, Bentrem DJ (2010) Crosstalk between mast cells and pancreatic cancer cells contributes to pancreatic tumor progression. Clin Cancer Res 16(8):2257-2265. doi:10.1158/1078-0432.CCR-09-1230

97. Cai SW, Yang SZ, Gao J, Pan K, Chen JY, Wang YL, Wei LX, Dong JH (2011) Prognostic significance of mast cell count following curative resection for pancreatic ductal adenocarcinoma. Surgery 149(4): 576-584. doi:10.1016/j.surg.2010.10.009

98. Johansson A, Rudolfsson S, Hammarsten P, Halin S, Pietras K, Jones J, Stattin P, Egevad L, Granfors T, Wikstrom P, Bergh A (2010) Mast cells are novel independent prognostic markers in prostate cancer and represent a target for therapy. Am J Pathol 177(2):1031-1041. doi:10. 2353/ajpath.2010.100070 